\title{
Seasonal Variation of Worldwide Solar Quiet of the Horizontal Magnetic Field Intensity
}

\author{
Owolabi, T. P. ${ }^{1,2}$, Rabiu, A. B. ${ }^{2,4}$, Olayanju, G. M. ${ }^{3} \&$ Bolaji, O. S. ${ }^{5}$ \\ ${ }^{1}$ African Regional Center for Space Science and Technology Education, Obafemi Awolowo University Campus \\ Ile Ife, Osun State, Nigeria \\ ${ }^{2}$ Department of Physics, Federal University of Technology, Akure, Ondo State, Nigeria \\ ${ }^{3}$ Department of Geophysics, Federal University of Technology, Akure, Ondo State, Nigeria \\ ${ }^{4}$ National Space Research and Development Agency, Abuja, Nigeria \\ ${ }^{5}$ Department of Physics, University of Lagos, Lagos, Nigeria \\ Correspondence: Owolabi T. P., African Regional Center for Space Science and Technology Education Obafemi \\ Awolowo University Campus Ile Ife Osun State, Nigeria. E-mail: topepascal2003@yahoo.com
}

Received: November 20, 2013 Accepted: December 6, $2013 \quad$ Online Published: February 25, 2014

doi:10.5539/apr.v6n2p82 URL: http://dx.doi.org/10.5539/apr.v6n2p82

\begin{abstract}
Numerous investigations have been carried out on many geomagnetic phenomena with a view of understanding the ionosphere. Solar Quiet $(\mathrm{Sq})$ is caused by electric currents induced in the Earth by the external source. We studied the variations of Sq over the various seasons Winter (November, December, January and February), Summer (May, June, July, August), Autumn (September, October) and Spring (March, April), using data from 64 geomagnetic stations for the year 1996 across the globe. The seasonal variations were studied across various latitudes and longitudes. Results show that $\mathrm{Sq}(\mathrm{H})$ exhibits transient variations with varying amplitude according to seasons of the year.
\end{abstract}

Keywords: ionosphere, Solar Quiet (Sq), transient variations

\section{Introduction}

On the Earth, human beings strongly attached their survival to technologies. These technologies are numerous ranging from food security to human capacity development. The study of space phenomena strongly relies on the coupling of magnetosphere, ionosphere and the thermosphere. To mention a few, consistent studies by Matsushita and Campbell (1967); Onwumechilli and Ogbuechi (1962); Price (1969); Rabiu (1996); Bolaji et al. (2013) on these coupling have yielded outstanding information regarding unsuitable perturbations that have been taken into considerations, which makes our continuous living on Earth conducive. The influence of ionospheric currents known as solar quiet $(\mathrm{Sq})$ currents of the ionosphere has played significant role of perturbations regarding the aforementioned coupling among magnetosphere, ionosphere and the thermosphere. Although, recent studies by Onwumechilli and Ogbuechi (1962); Rabiu (1996); Bolaji et al. (2013) on Sq currents were deduced from the horizontal $(\mathrm{H})$ intensity of a geomagnetic field. But, the first study on the daily variation of Sq of the $\mathrm{H}$ intensity was carried out by Graham in 1722. During his study, he noted sluggish, regular and irregular changes of declination on different days. He observed that this irregular variability is sometimes larger and more rapid on some days and he referred to such variability as geomagnetic stormy days. From his study, he made suggestions by distinguishing between magnetically quiet, moderately disturbed and highly disturbed days. His studies reveal that daily variations of Sq are different from one day to another, which is based on classification of days into quiet, moderately disturbed and strongly disturbed periods. Different studies have shown that studying Sq variability during a very quiet period avail the opportunity to understand the morphologies of the ionosphere and its interaction with the magnetosphere. Campbell (1976) worked on the spectral characteristics of field variations during geomagnetic quiet conditions. From his work, he observed highest, moderate and enhanced spectral amplitudes at high latitude, low latitude and equatorial region, in that order. He further observed that spatial and temporal features of the spectral for quiet days are closely similar to that observed on geomagnetic disturbed days. Analysis of spherical harmonics that was initiated by Gauss (1839) was employed by Suzuki (1977) to study geomagnetic Sq field. He observed that universal time (UT) variability are made up of two parts; 
the regular variations during quiet period $(\mathrm{Sq})$ and the occasional variation during very disturbed period (irregular known as $S_{R}$, Maeda (1968)).

Mitra (1947); Schlapps (1968); Onwumechilli and Ogbuechi (1962); Rabiu (1996, 2002); Okeke and Rabiu (1998) have investigated Sq day-to-day variations at low and middle latitudes during very quiet period. Irrespective of latitudinal differences, Mitra (1947); Rabiu (1996, 2002); Okeke and Rabiu (1998) observed higher magnitudes of Sq of $\mathrm{H}$ during daytime period (0600-1800 local time, LT) compare to the nighttime hours (1900-0500 LT). They reported the effect of ionospheric dynamo from ionospheric conductivity as being responsible for the higher variability of Sq of $h$ during daytime. Okeke and Rabiu (1998) and Rabiu $(1996,2002)$ suggested that these smaller Sq of $\mathrm{H}$ variability observed during nighttime hours (nocturnal period) are not from ionospheric sources, but, from non-ionospheric sources like magnetospheric and ring currents. Onwumechilli and Ogbuechi found that the amplitude of Sq depends on local time and the strength of Sq currents that enhanced at the dip equator. During International Geophysical Year (IGY), Schlapp (1968) participated in the investigation of worldwide day-to-day variability of Sq of $\mathrm{H}$. He observed anisotropy phenomenon, a rapid and higher decrease in $\mathrm{Sq}$ of $\mathrm{H}$ magnitudes at the middle latitude (European stations) and lowest decrease at the equator. He suggested that variability with separation is faster at latitudes compare to longitudes. Ten (10) year after IGY, Greener and Schlapps (1978) investigated Sq of H day-to-day variability over Europe. They observed a greater coherent length in the east-west direction compare to north-south direction. They attributed that this greater coherence is due to a spatial coherence observed at middle latitude region in the order of $2000 \mathrm{Km}$.

However, studies on Sq of $\mathrm{H}$ are not limited to diurnal, spatial, temporal and day-to-day variability. Studies on $\mathrm{Sq}$ of $\mathrm{H}$ have also been conducted regarding seasons with respect to solar cycle, annual and semi annual variability. For example, Yacob and Rao (1965) studied the solar cycle and annual variations of Sq (H) at Alibag in India, a low latitude region. They observed a higher magnitude of Sq of $\mathrm{H}$ during the summer months, which is equivalent to June (J) season and a lowest magnitude during the winter months, which is equivalent to December (D) season. Maeda (1968) and Suzuki (1973) observed that Sq current intensities at J-season and equinoctial periods are almost equal over American sector. Santarelli et al. (2007) investigated geomagnetic daily variation of Sq of $\mathrm{H}$ at Mario Zucchelli station, Antarctica in Italy, a middle latitude station. Using fourteen years of magnetic data, they found a higher magnitude of $\mathrm{Sq}$ of $\mathrm{H}$ during J-season and a lower magnitude of $\mathrm{Sq}$ of $\mathrm{H}$ during D-season. Rastogi (1992) and Onwumechilli et al. (1994) have studied geomagnetic field variations of Sq of $\mathrm{H}$ at India stations, a low latitude sector. They observed maxima magnitudes of $\mathrm{Sq}$ of $\mathrm{H}$ during equinoctial months and the lowest magnitudes of $\mathrm{Sq}$ of $\mathrm{H}$ at noon hours during J-season, which indicates a semi-annual variability as well. Further effort by Vestine (1954) suggested that the meridional ionospheric wind blowing from summer to winter hemispheres explains the annual variation of Sq of $\mathrm{H}$ and that of Olson (1970b) postulated a single current system flowing on the magnetopause as the explanation regarding the daily, semi-annual and annual variations of $\mathrm{Sq}$ of $\mathrm{H}$. Recently, Yamasaki et al. (2011) worked on the intensity variations of the equivalent Sq current system along the $210^{\circ}$ magnetic meridian in Asia using data base of Magnetic Data Acquisition System (MAGDAS). They observed higher magnitudes during J-season compare to D-season. They found that the total current intensity ( $\mathrm{J}$ total) variability are mainly controlled by solar radiation activity and the impact of seasonal and day-to-day effects are about half of the solar activity contributions as well. Pham Thi Thu et al. (2011) also studied the Sq field characteristics at Phu Thuy, Vietnam, during solar cycle 23 and comparison its variability with $\mathrm{Sq}$ field at other longitudinal sectors. Their results show that Sq fields exhibit equinoctial and diurnal asymmetry. These indicate that the seasonal variation of the monthly mean of X-component exhibit a semi-annual signature having two equinoctial maxima. On global scale, Takeda (1999) excluded assumption of north-south symmetry on the time variations of global geomagnetic Sq field in year 1964 and 1980. He observed that the intensity of the vortex in the year 1980 (a solar maximum year) was almost twice as large as that of year 1964 (a solar minimum year). He observed that in the year 1980, the intensity of Sq was varying with a period of about 10-15 days such that the phase is advanced with respect to earlier universal time or to the east side of the globe. He then suggested that the intensity in the two hemispheres vary out of phase with respect to one another and ignores seasonal variability.

Although, the aforementioned literatures have shown that several studies on Sq of $\mathrm{H}$ variability have been conducted regionally, but, without any consideration regarding coordinated seasonal variability. Hence, this shortcoming is due to shortage of coordinated observatories, otherwise, owing to increasing geomagnetic observatories either singly or through collaborative efforts, it worth conducting investigation on seasonal variability of $\mathrm{Sq}$ of $\mathrm{H}$. In this work, 64 observatories across the world accommodating the northern and southern hemisphere during a very quiet period (1996) will be investigated. 


\section{Methodology}

The geomagnetic data employed for this study were retrieved from International Real-time Magnetic Observatory Networks (INTERMAGNET) shown in Figure 1. INTERMAGNET is a global network of geomagnetic observatories, where the Earth magnetic field intensities are being monitor. The data from 64 stations at different latitudinal and longitudinal zones in the year 1996, a low solar active year were used for this study. A year data that was recorded simultaneously from each zone are investigated. The year 1996, being a low solar active period during the solar cycle 22 has an annual sunspot number of 8.6. This annual sunspot number of 8.6 implies that the year 1996 has lesser geomagnetic disturbances coupled with higher number of spotless days in reference to sunspot number. These are stronger indicators that solar quiet (Sq) studies during this year (1996) will give better morphologies about its variability compare to year with higher sunspot number and geomagnetic disturbances. The reason is that the best period to study Sq variability is during period with no or lesser disturbances in the ionosphere. Hence, the choice for international quiet days (IQDs) within the year 1996, otherwise, disturbed days could be involved. The Geosciences Australia at www.ga.gov.au/oracle/geomag/iqd/_form.jsp contains list of IQDs that was described as the quietest days in a month. The most five quietest days were selected from each month of the year 1996 to study geomagnetic intensity of the horizontal $(\mathrm{H})$ component.

The encrypted recorded INTERMAGNET H component data in minutes are decoded and converted to hourly values using codes writing with MATLAB ${ }^{\circledR}$ program. These $\mathrm{H}$ geomagnetic field intensities hourly values of the most five quietest days were taken from each month over all the 64 stations. For Sq of $\mathrm{H}$ component computation, the baseline value of $\mathrm{H}\left(H_{o}\right)$ was define as the average value of $\mathrm{H}$ component near local midnight between 2400 local time (LT) and 0100 LT. This is expressed mathematically as follows:

$$
H_{o}=\frac{H_{01}+H_{24}}{2}
$$

Where $H_{01}$ and $H_{24}$ are the hourly values of $\mathrm{H}$ component at $0100 \mathrm{LT}$ and $2400 \mathrm{LT}$, respectively. The hourly departure $(\delta H)$ is equal to the residual value after subtracting a day $H_{o}$ value from each hourly value of $\mathrm{H}$ component. That is,

$$
\delta H_{t}=H_{t}-H_{o}
$$

This $\delta H$ is the equivalent to the $\mathrm{Sq}$ of $\mathrm{H}$, where $\mathrm{t}=1$ to 24 hours. These analyses are carried out on all quietest five days in a month over all the year 1996 and across all stations under investigation. The deduced Sq of $\mathrm{H}$ are further corrected for non-cyclic variations, a phenomenon where the value at 0100 LT is not different from the value at 2400 LT. This method has been employed by Vestine (1947) and Rabiu (2002). For seasonal variation, the hourly values for five quietest days in each month were averaged. This average result to a monthly mean that was then classified into four seasons; winter (November, December, January and February), summer (May, June, July, August), autumn (September, October) and spring (March, April). These estimated seasonal values were then plotted with surfer 8 application to generate the worldwide three dimensional plots results that will be discuss later. However, using the capability of Surfer 8 application, some zones where INTERMAGNET geomagnetic stations did not exist, which could have indicated absence of data-points on the seasonal plots were interpolated. The 64 geomagnetic observatories under investigation are tabulated below.

\begin{tabular}{|c|c|c|c|c|c|c|}
\hline $\mathrm{S} / \mathrm{N}$ & STATION & NAME & & COUNTRY & $\begin{array}{l}\text { CO-LATITUDE } \\
\text { (DEG) }\end{array}$ & $\begin{array}{l}\text { LONGITUDE } \\
(\mathrm{DEG} / \mathrm{E})\end{array}$ \\
\hline 1 & $\mathrm{ABK}$ & $\begin{array}{l}\text { ABISKO } \\
\text { INFORM }\end{array}$ & OBSERVATORY & SWEDEN & 21.64 & 18.82 \\
\hline 2 & ALE & $\begin{array}{l}\text { ALERT } \\
\text { INFORM }\end{array}$ & OBSERVATORY & CANADA & 7.50 & 297.65 \\
\hline 3 & AMS & $\begin{array}{l}\text { AMSTERDAM } \\
\text { OBSERVATORY }\end{array}$ & ISLAND & FRANCE & 127.80 & 77.57 \\
\hline 4 & BDV & $\begin{array}{l}\text { BUDKOV } \\
\text { INFORM }\end{array}$ & OBSEVATORY & $\begin{array}{l}\text { CZECH } \\
\text { REPUBLIC }\end{array}$ & 40.92 & 14.02 \\
\hline
\end{tabular}

Table 1. Study locations with their latitude and longitude 


\begin{tabular}{|c|c|c|c|c|c|c|}
\hline 5 & BEL & $\begin{array}{l}\text { BELSK } \\
\text { INFOR }\end{array}$ & OBSERVATORY & POLAND & 38.16 & 20.79 \\
\hline 6 & BFE & $\begin{array}{l}\text { BRORFELDE } \\
\text { INFOM }\end{array}$ & OBSERVATORY & DENMARK & 34.37 & 11.67 \\
\hline 7 & BLC & $\begin{array}{l}\text { BAKER LAKE } \\
\text { INFOM }\end{array}$ & OBSERVATORY & CANADA & 25.67 & 263.97 \\
\hline 8 & $\mathrm{BNG}$ & $\begin{array}{l}\text { BANGUI } \\
\text { INFORM }\end{array}$ & OBSERVATORY & $\begin{array}{l}\text { CENTRAL AFRI } \\
\text { REP }\end{array}$ & 85.67 & 18.566 \\
\hline 9 & $\mathrm{BOU}$ & $\begin{array}{l}\text { BOULDER } \\
\text { INFORM }\end{array}$ & OBSERVATORY & USA & 49.86 & 254.76 \\
\hline 10 & BRW & $\begin{array}{l}\text { BARROW } \\
\text { INFORM }\end{array}$ & OBSERVATORY & USA & 18.62 & 203.38 \\
\hline 11 & BSL & $\begin{array}{l}\text { BAY } \\
\text { OBSERVATOR }\end{array}$ & $\begin{array}{l}\text { ST.LOUIS } \\
\text { Y INFORM }\end{array}$ & USA & 59.60 & 270.60 \\
\hline 12 & $\mathrm{CBB}$ & $\begin{array}{l}\text { CAMBRIDGE } \\
\text { OBSERVATOR }\end{array}$ & Y INFO & CANADA & 20.88 & 254.97 \\
\hline 13 & CLF & $\begin{array}{l}\text { CHAMBON } \\
\text { OBSERVATOR }\end{array}$ & $\begin{array}{l}\text { LA } \\
Y\end{array}$ & FRANCE & 41.98 & 2.27 \\
\hline 14 & $\mathrm{CMO}$ & $\begin{array}{l}\text { COLLEGE } \\
\text { INFORM }\end{array}$ & OBSERVATORY & USA & 25.14 & 212.16 \\
\hline 15 & $\mathrm{CNB}$ & $\begin{array}{l}\text { CANBERRA } \\
\text { INFORM }\end{array}$ & OBSERVATORY & AUSRALLIA & 125.31 & 149.36 \\
\hline 16 & $\mathrm{CZT}$ & $\begin{array}{l}\text { CROZET } \\
\text { INFORM }\end{array}$ & OBSERVATORY & FRANCE & 136.43 & 51.86 \\
\hline 17 & DLR & $\begin{array}{l}\text { DEL RIO } \\
\text { INFORM }\end{array}$ & OBSERVATORY & USA & 60.51 & 259.08 \\
\hline 18 & DRV & DUMONT d' Ul & RVILLE & FRANCE & 156.67 & 140.01 \\
\hline 19 & ESK & $\begin{array}{l}\text { ESKDALEMUI } \\
\text { OBSERVATOR }\end{array}$ & $\begin{array}{l}\text { IR } \\
\text { Y INFORM }\end{array}$ & UK & 34.70 & 356.80 \\
\hline 20 & EYR & $\begin{array}{l}\text { EYREWELL } \\
\text { INFORM }\end{array}$ & OBSERVATORY & $\begin{array}{l}\text { NEW } \\
\text { ZEALAND }\end{array}$ & 133.42 & 172.35 \\
\hline 21 & FCC & $\begin{array}{l}\text { FORT } \\
\text { OBSERVATOR }\end{array}$ & $\begin{array}{l}\text { CHURCHILL } \\
\text { Y }\end{array}$ & CANADA & 31.24 & 265.91 \\
\hline 22 & FRD & $\begin{array}{l}\text { FREDERICKSE } \\
\text { OBSERVATOR }\end{array}$ & $\begin{array}{l}\text { BURG } \\
Y\end{array}$ & USA & 51.80 & 282.63 \\
\hline 23 & FRN & $\begin{array}{l}\text { FRESNO } \\
\text { INFORM }\end{array}$ & OBSERVATORY & USA & 52.91 & 240.28 \\
\hline 24 & FUR & $\begin{array}{l}\text { FUERSTENFEI } \\
\text { OBSERVATOR }\end{array}$ & $\begin{array}{l}\text { LDBRUCK } \\
Y\end{array}$ & GERMANY & 41.84 & 11.28 \\
\hline 25 & GDH & $\begin{array}{l}\text { GODHAVN } \\
\text { INFORM }\end{array}$ & OBSERVATORY & DENMARK & 20.75 & 306.47 \\
\hline 26 & GLN & $\begin{array}{l}\text { GLENLEA } \\
\text { INFORM }\end{array}$ & OBSERVATORY & CANADA & 40.36 & 262.88 \\
\hline 27 & GNA & $\begin{array}{l}\text { GNANGARA } \\
\text { INFORM }\end{array}$ & OBSERVATORY & AUSRALIA & 121.80 & 116.00 \\
\hline 28 & GUA & $\begin{array}{l}\text { GUAM } \\
\text { INFORM }\end{array}$ & OBSERVATORY & USA & 76.42 & 144.87 \\
\hline 29 & HAD & HARTLAND & OBSERVATORY & UK & 39.00 & 355.50 \\
\hline
\end{tabular}




\begin{tabular}{|c|c|c|c|c|c|c|}
\hline & & INFORM & & & & \\
\hline 30 & HER & $\begin{array}{l}\text { HERMANUS } \\
\text { OBSERVATOR }\end{array}$ & MAGNETIC & $\begin{array}{l}\text { SOUTH } \\
\text { AFRICA }\end{array}$ & 124.43 & 19.23 \\
\hline 31 & $\mathrm{HON}$ & $\begin{array}{l}\text { HONOLOLU } \\
\text { INFORM }\end{array}$ & OBSERVATORY & USA & 68.68 & 202.00 \\
\hline 32 & IQA & $\begin{array}{l}\text { IQALUIT } \\
\text { INFORM }\end{array}$ & OBSERVATORY & CANADA & 26.25 & 291.48 \\
\hline 33 & KAK & $\begin{array}{l}\text { KAKIOKA } \\
\text { INFORM }\end{array}$ & OBSERVATORY & JAPAN & 53.77 & 140.18 \\
\hline 34 & $\mathrm{KOU}$ & $\begin{array}{l}\text { KOUROU } \\
\text { INFORM }\end{array}$ & OBSERVATORY & FRANCE & 87.79 & 307.27 \\
\hline 35 & LER & $\begin{array}{l}\text { LERWICK } \\
\text { INFORM }\end{array}$ & OBSERVATORY & UK & 29.90 & 358.80 \\
\hline 36 & LOV & $\begin{array}{l}\text { LOVO } \\
\text { INFORM }\end{array}$ & OBSERVATORY & SWEDEN & 30.66 & 17.82 \\
\hline 37 & $\mathrm{MBC}$ & $\begin{array}{l}\text { MOULD BAY } \\
\text { INFORM }\end{array}$ & OBSERVATORY & CANADA & 13.69 & 240.64 \\
\hline 38 & $\mathrm{MBO}$ & $\begin{array}{l}\text { MBOUR } \\
\text { INFORM }\end{array}$ & OBSERVATORY & SENEGAL & 75.62 & 343.03 \\
\hline 39 & MEA & $\begin{array}{l}\text { MEAOOK } \\
\text { INFORM }\end{array}$ & OBSERVATORY & CANADA & 35.38 & 246.65 \\
\hline 40 & MMB & $\begin{array}{l}\text { MEMAMBETS } \\
\text { OBSERVATOR }\end{array}$ & SU INFORM & JAPAN & 46.10 & 144.20 \\
\hline 41 & NAQ & $\begin{array}{l}\text { NARSARSUA } \\
\text { OBSERVATOR }\end{array}$ & $\begin{array}{l}\text { Q } \\
\text { Y INFORM }\end{array}$ & DENMARK & 28.84 & 314.56 \\
\hline 42 & NCK & $\begin{array}{l}\text { NAGYCENK } \\
\text { INFORM }\end{array}$ & OBSERVATORY & HUNGARY & 42.37 & 16.72 \\
\hline 43 & NEW & $\begin{array}{l}\text { NEWPORT } \\
\text { INFORM }\end{array}$ & OBSERVATORY & USA & 41.74 & 242.88 \\
\hline 44 & NGK & $\begin{array}{l}\text { NIEMEGK } \\
\text { INFORM }\end{array}$ & OBSERVATORY & GERMANY & 37.93 & 12.68 \\
\hline 45 & NUR & $\begin{array}{l}\text { NURMIJARVI } \\
\text { INFORM }\end{array}$ & OBSERVATORY & FINLAND & 29.49 & 24.66 \\
\hline 46 & OTT & $\begin{array}{l}\text { OTTAWA } \\
\text { INFORM }\end{array}$ & OBSERVATORY & CANADA & 44.60 & 284.45 \\
\hline 47 & PAF & $\begin{array}{l}\text { PORT-AUX-FR } \\
\text { OBSERVATOR }\end{array}$ & $\begin{array}{l}\text { RANCAIS } \\
\text { Y }\end{array}$ & FRANCE & 139.35 & 70.26 \\
\hline 48 & PBQ & $\begin{array}{l}\text { POSTE-DE-LA } \\
\text { OBSERVATOR }\end{array}$ & $\begin{array}{l}\text {-BALEINE } \\
Y\end{array}$ & CANADA & 34.72 & 282.26 \\
\hline 49 & PHU & $\begin{array}{l}\text { PHUHUY } \\
\text { INFORM }\end{array}$ & OBSERVATORY & VIETNAM & 68.97 & 105.95 \\
\hline 50 & PPT & $\begin{array}{l}\text { PAMATAI } \\
\text { INFORM }\end{array}$ & OBSERVATORY & FRANCE & 107.57 & 210.41 \\
\hline 51 & RES & $\begin{array}{l}\text { RESOLUTE } \\
\text { OBSERVATOR }\end{array}$ & Y INFOR & CANADA & 15.31 & 265.10 \\
\hline 52 & SBA & $\begin{array}{l}\text { SCOTT BASE } \\
\text { INFORM }\end{array}$ & OBSERVATORY & $\begin{array}{l}\text { NEW } \\
\text { ZEALAND }\end{array}$ & 167.85 & 172.78 \\
\hline 53 & SIT & SITKA & OBSERVATORY & USA & 32.94 & 224.67 \\
\hline
\end{tabular}




\begin{tabular}{|c|c|c|c|c|c|c|}
\hline & & INFORM & & & & \\
\hline 54 & SJG & $\begin{array}{l}\text { SAN JUAN } \\
\text { INFORM }\end{array}$ & OBSERVATORY & USA & 71.89 & 293.85 \\
\hline 55 & SOD & $\begin{array}{l}\text { SODANKYLA } \\
\text { OBSER }\end{array}$ & GEOPHYSICAL & FINLAND & 22.63 & 26.63 \\
\hline 56 & STJ & $\begin{array}{l}\text { ST. JOHN'S } \\
\text { INFORM }\end{array}$ & OBSERVATORY & CANADA & 42.41 & 307.32 \\
\hline 57 & AMS & $\begin{array}{l}\text { TAMANRASS } \\
\text { OBSERVATOR }\end{array}$ & $\begin{array}{l}\text { ET } \\
\text { Y INFO }\end{array}$ & ALGERIA & 67.21 & 5.53 \\
\hline 58 & TAN & $\begin{array}{l}\text { TANANARIVE } \\
\text { OBSERVATOR }\end{array}$ & Y INFORM & MADAGASCAR & 108.92 & 47.53 \\
\hline 59 & THL & $\begin{array}{l}\text { THULE } \\
\text { INFORM }\end{array}$ & OBSERVATORY & DENMARK & 12.53 & 290.77 \\
\hline 60 & THY & $\begin{array}{l}\text { TIHANY } \\
\text { INFORM }\end{array}$ & OBSERVATORY & HUNGARY & 43.10 & 17.54 \\
\hline 61 & TUC & $\begin{array}{l}\text { TUCSON } \\
\text { INFORM }\end{array}$ & OBSERVATORY & USA & 57.75 & 249.17 \\
\hline 62 & VIC & $\begin{array}{l}\text { VICTORIA } \\
\text { INFORM }\end{array}$ & OBSERVATORY & CANADA & 41.48 & 236.58 \\
\hline 63 & WNG & $\begin{array}{l}\text { WINGST } \\
\text { INFORM }\end{array}$ & OBSERVATORY & GERMANY & 36.26 & 9.07 \\
\hline 64 & YKC & $\begin{array}{l}\text { YELLOW } \\
\text { OBSERVATOR }\end{array}$ & Y INFOR & CANADA & 27.52 & 245.52 \\
\hline
\end{tabular}

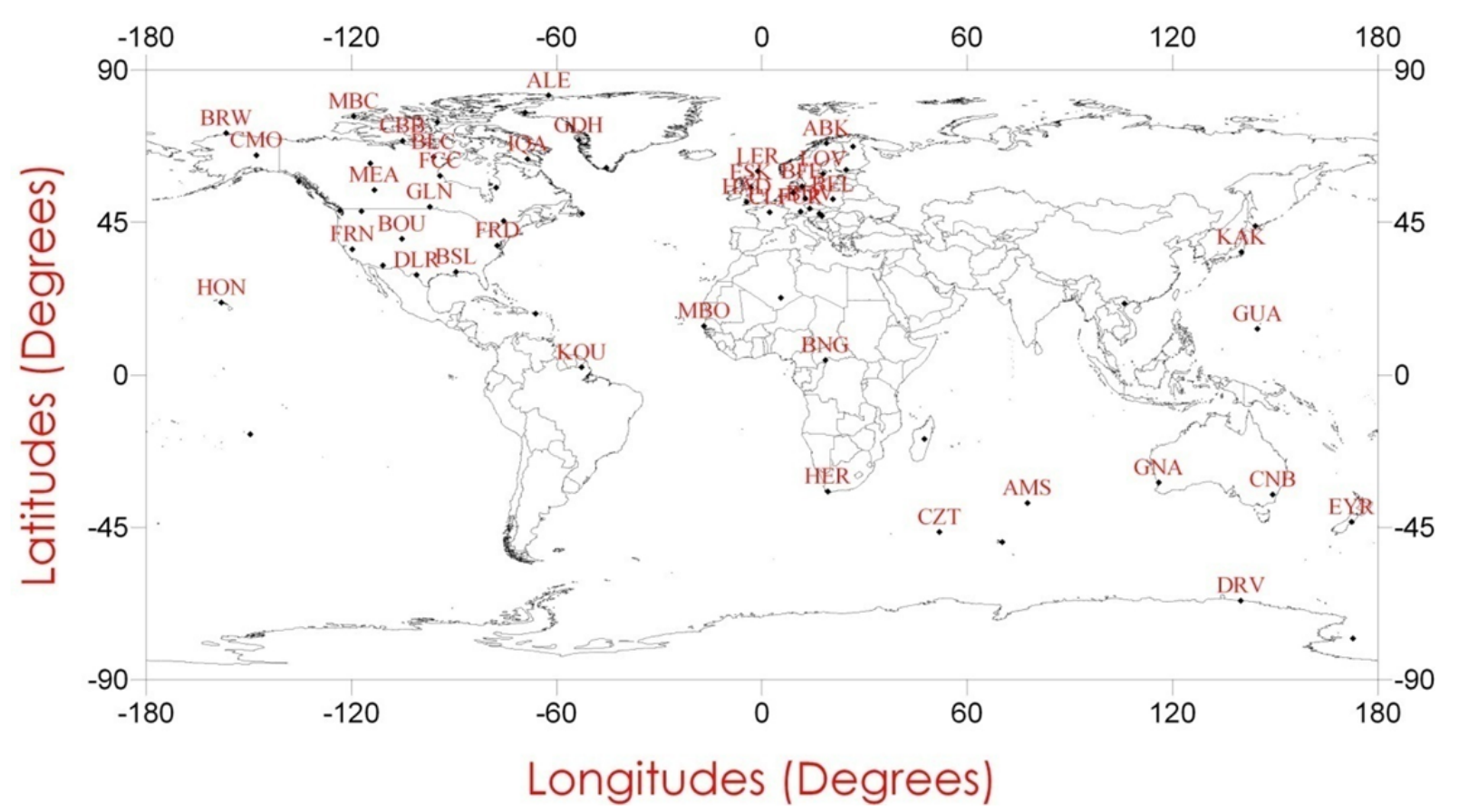

Figure 1. Map of the world showing locations of the 64 observatories used in the research 


\section{Results}

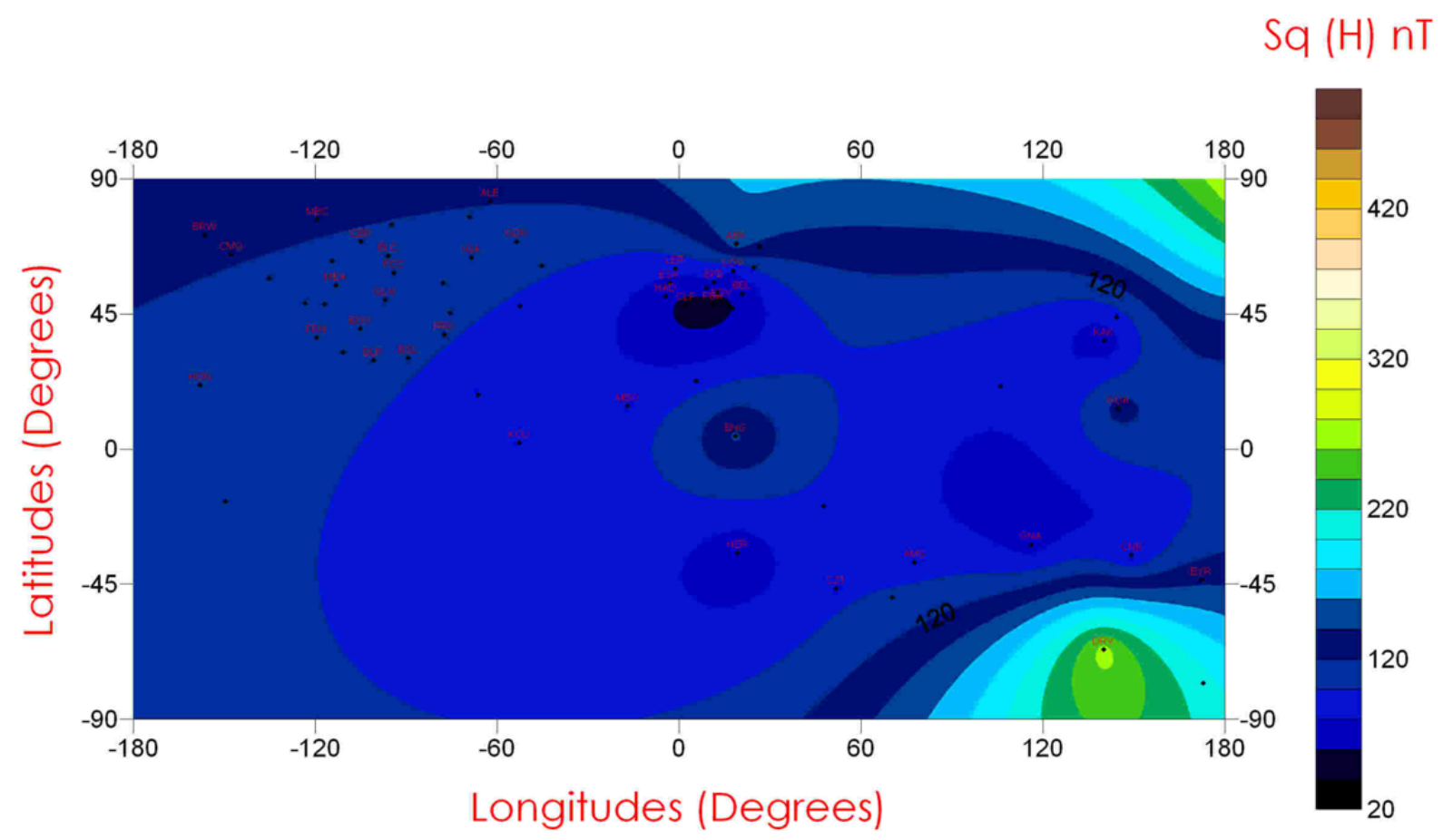

Figure 2. Sq $(\mathrm{H})$ during E- season

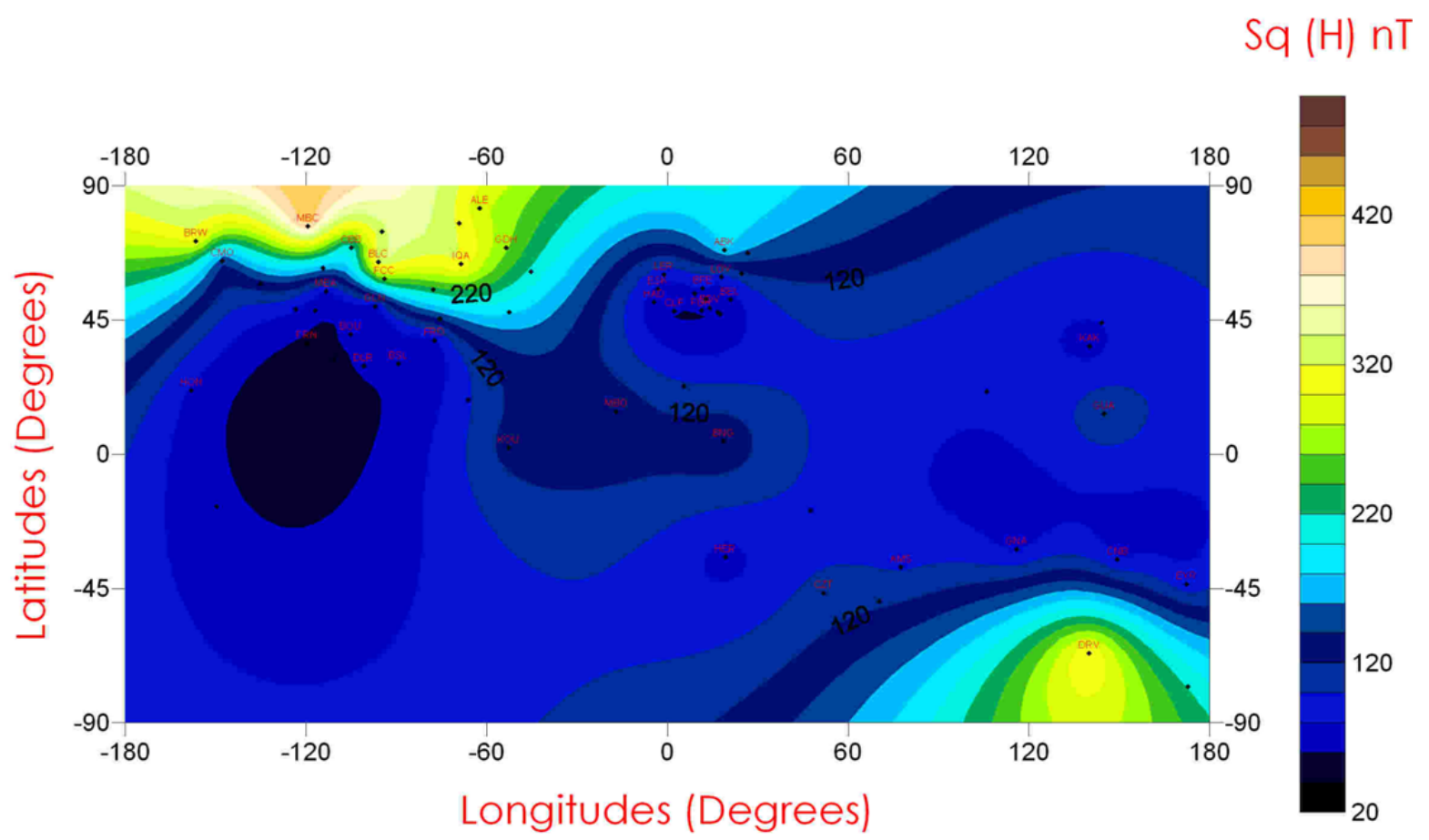

Figure 3. Sq (H) during E- season (Autumn) 


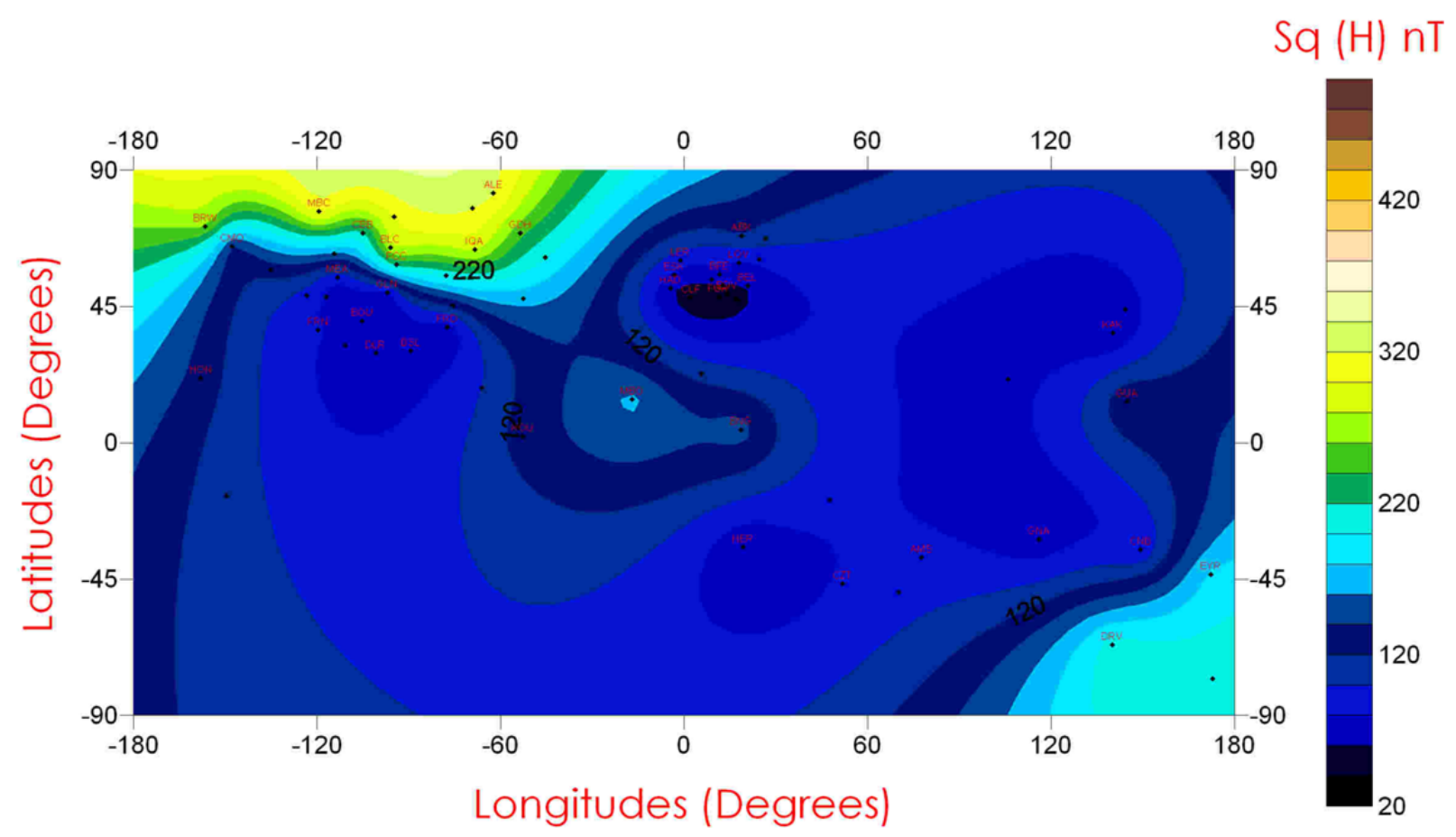

Figure 4. Sq (H) during E- season(Spring)

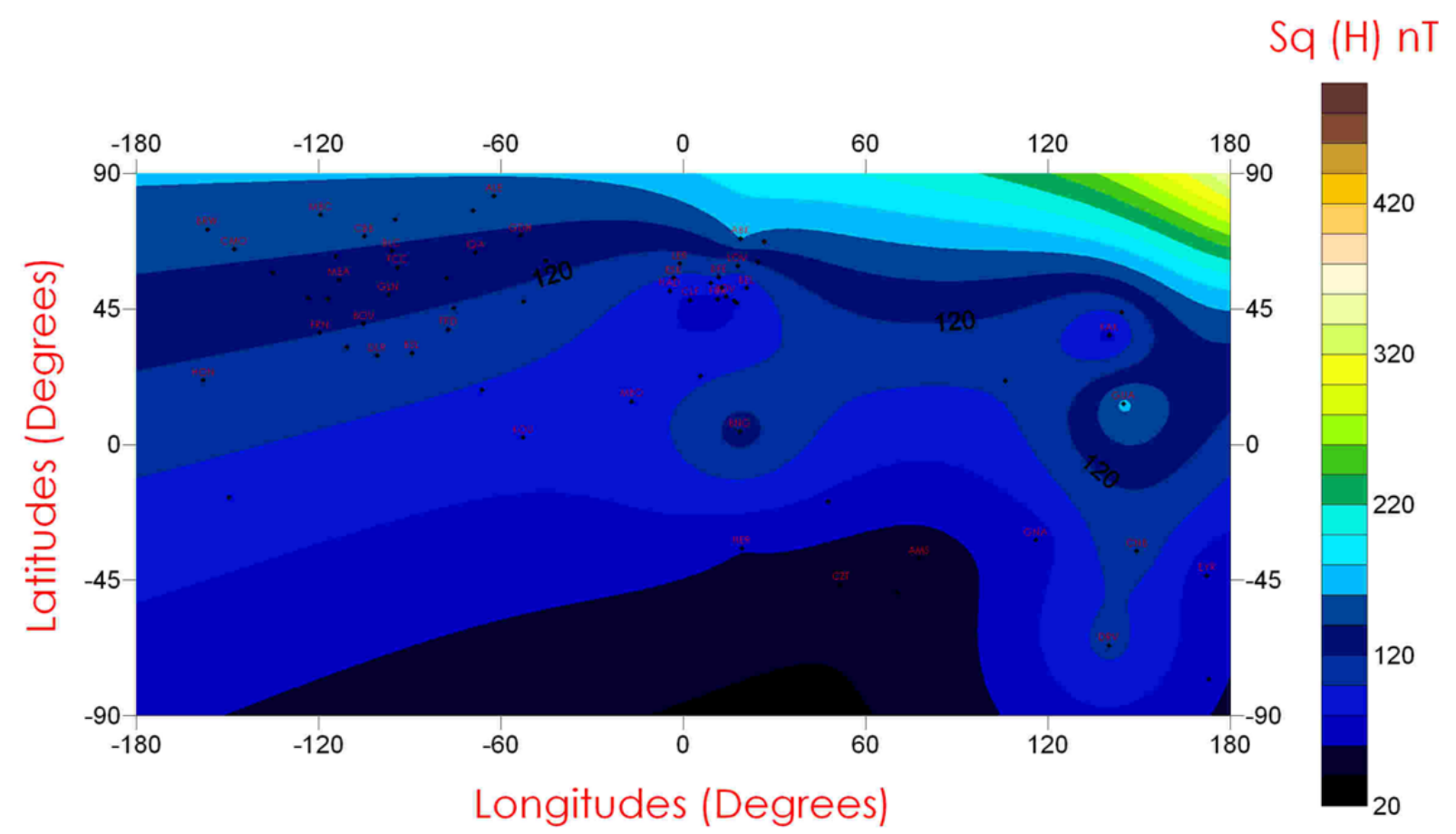

Figure 5. Sq (H) during J- season (June Solstice) 


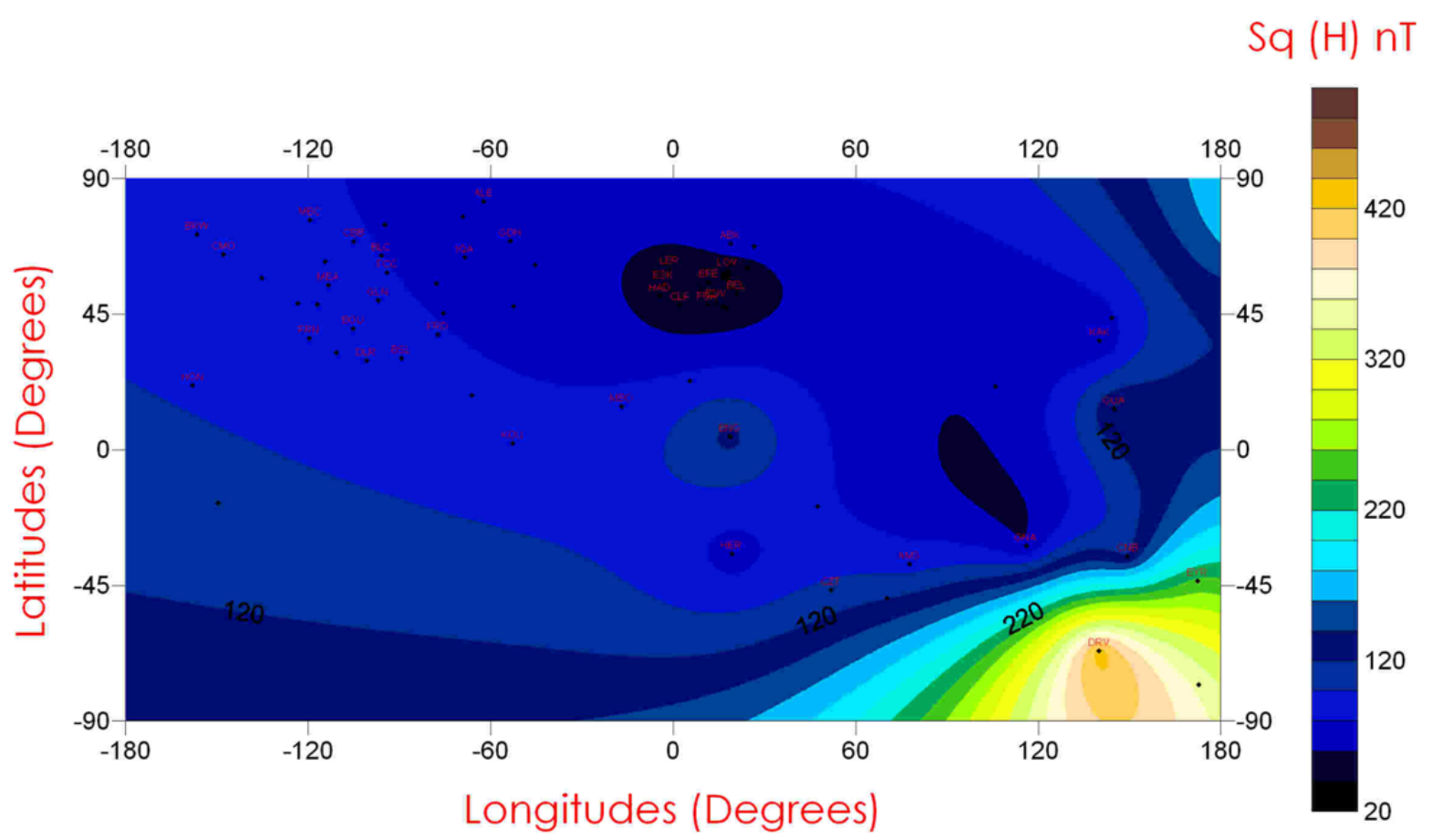

Figure 6. Sq (H) during D- season (December Solstice)

\section{Discussion}

Figures 2 to 5 show worldwide seasonal variations of solar quiet field of the horizontal intensities, Sq $(\mathrm{H})$ during E-season (Autumn), E-season (Spring), J-season (June Solstice) and D-season (December Solstice). In Figure 2, during Autumn E-season, magnitudes of $\mathrm{Sq}(\mathrm{H})$ at the western longitude $\left(60^{\circ} \mathrm{W}-180^{\circ} \mathrm{W}\right)$ are in the range between $\sim 240 \mathrm{nT}$ and $\sim 440 \mathrm{nT}$ at high latitude around $60^{\circ} \mathrm{N}$ to $90^{\circ} \mathrm{N}$. On the same western longitude $\left(60^{\circ} \mathrm{W}-\right.$ $\left.180^{\circ} \mathrm{W}\right)$ at the middle latitude $\left(30^{\circ} \mathrm{N}-60^{\circ} \mathrm{N}\right)$, Autumn E-season magnitudes of Sq $(\mathrm{H})$ were observed to significantly reduce to between $\sim 60 \mathrm{nT}$ and $\sim 180 \mathrm{nT}$. Although, around the low latitude $\left(0^{\circ} \mathrm{N}-30^{\circ} \mathrm{N}\right)$, the Sq (H) magnitudes further reduce to $\sim 20 \mathrm{nT}$ and $\sim 40 \mathrm{nT}$, but, between the western zone $\left(\sim 60^{\circ} \mathrm{W}\right)$ and eastern zone $\left(\sim 58^{\circ} \mathrm{E}\right)$ through the equator $\left(0^{\circ}\right)$ to the low latitude $\left(0^{\circ} \mathrm{S}-30^{\circ} \mathrm{S}\right)$ at southern hemisphere, the Autumn E-season magnitudes of $\mathrm{Sq}(\mathrm{H})$ were observed to slightly increased to between the range of $\sim 120 \mathrm{nT}$ and $\sim 140 \mathrm{nT}$. Beyond the low latitude to high latitude at the southern hemisphere around $60^{\circ} \mathrm{W}-180^{\circ} \mathrm{W}$, the Autumn E-season magnitudes of Sq $(\mathrm{H})$ are between $\sim 40 \mathrm{nT}$ and $60 \mathrm{nT}$. Minimal Autumn E-seasonal magnitudes of $\mathrm{Sq}(\mathrm{H})$ in the range of $\sim 60 \mathrm{nT}$ to $\sim 130 \mathrm{nT}$ were observed from the high latitude (northern hemisphere) to middle latitude in the southern hemisphere through the low latitude around $60^{\circ} \mathrm{E}-180^{\circ} \mathrm{E}$. Gradual increments were observed from the middle latitude in the southern hemisphere around $60^{\circ} \mathrm{E}-180^{\circ} \mathrm{E}$ to the high latitude. These gradual increments were in the range of $\sim 170 \mathrm{nT}$ to $\sim 320 \mathrm{nT}$, with the highest magnitude of $\sim 320 \mathrm{nT}$ observed at high latitude and the lowest magnitude of $\sim 170 \mathrm{nT}$ observed at the middle latitude. The signature of Spring E-seasonal variability in Figure 3 is similar to that of Autumn E-seasonal variability (Figure 2). Irrespective of similarity in their patterns of variability, the Autumn E-season $\mathrm{Sq}(\mathrm{H})$ magnitudes are always greater than the Spring E-season Sq $(\mathrm{H})$ magnitudes. For instance, at $60^{\circ} \mathrm{N}$ to $90^{\circ} \mathrm{N}$ around $60^{\circ} \mathrm{W}-180^{\circ} \mathrm{W}$, reduced Spring E-season Sq (H) magnitudes in the range of $\sim 220 \mathrm{nT}$ to $\sim 300 \mathrm{nT}$ were observed compare to Autumn E-season $\mathrm{Sq}(\mathrm{H})$ magnitudes in the range of $\sim 240 \mathrm{nT}$ to $\sim 440 \mathrm{nT}$. At the high latitude of the southern hemisphere around $120^{\circ} \mathrm{E}-180^{\circ} \mathrm{E}$, reduction in $\mathrm{Sq}(\mathrm{H})$ magnitudes of Spring E-season were as well observed compare to higher Sq (H) magnitudes of Autumn E-season. Around $120^{\circ} \mathrm{E}-180^{\circ} \mathrm{E}$, these reductions have consistent value of $\sim 220 \mathrm{nT}$ compare to Autumn E-seasonal magnitudes in the range between $\sim 170 \mathrm{nT}$ and $\sim 320 \mathrm{nT}$. The surprised increment in equinoctial $\mathrm{Sq}(\mathrm{H})$ magnitude at the equatorial region within the low latitude indicates re-injection of ionospheric current, which was reported by Chapman (1951) as being initiated by equatorial electrojet current (EEJ). This comparison between Autumn and Spring E-seasonal magnitudes at all latitudes and longitudes shows that $\mathrm{Sq}(\mathrm{H})$ seasonal magnitudes during Autumn is always higher than that of Spring period.

Figure 4 shows worldwide variability of $\mathrm{Sq}(\mathrm{H})$ magnitudes during J-season (June solstice) ranging between $\sim 20$ 
$\mathrm{nT}$ and $\sim 180 \mathrm{nT}$ across all latitudes and longitudes. Highest values in the range of $\sim 80 \mathrm{nT}-\sim 140 \mathrm{nT}$ were observed at all equatorial regions within low latitude across all longitudes. Lowest values in the range of $\sim 20 \mathrm{nT}$ $-\sim 40 \mathrm{nT}$ were observed at southern hemisphere of the high latitude around $150^{\circ} \mathrm{W}-110^{\circ} \mathrm{E}$ and crept slightly into the middle latitude around $60^{\circ} \mathrm{E}-110^{\circ} \mathrm{E}$. An exception was observed at northern hemisphere of high latitude between $60^{\circ} \mathrm{E}$ and $180^{\circ} \mathrm{E}$. This exception is an attribute of increments at northern hemisphere of high latitude between $60^{\circ} \mathrm{E}$ and $180^{\circ} \mathrm{E}$. These increments of $\mathrm{Sq}(\mathrm{H})$ magnitudes during June solstice were gradual around $45^{\circ} \mathrm{N}$ and $60^{\circ} \mathrm{E}$ and with highest magnitudes of $\sim 320 \mathrm{nT}$ between $90^{\circ} \mathrm{N}$ and $180^{\circ} \mathrm{E}$. A worldwide $\mathrm{Sq}(\mathrm{H})$ variability pattern similar to June solstice was observed from D-season (December solstice), but, in opposite pattern regarding increments of $\mathrm{Sq}(\mathrm{H})$ magnitudes. This opposite pattern regarding increments of $\mathrm{Sq}(\mathrm{H})$ magnitudes was initiated around $43^{\circ} \mathrm{S}$ and extended with continuous increments to the southern hemisphere of high latitude around $8^{\circ} \mathrm{E}-180^{\circ} \mathrm{E}$. The highest $\mathrm{Sq}(\mathrm{H})$ magnitude during December solstice between $50^{\circ} \mathrm{S}$ and $130^{\circ} \mathrm{E}$ of the southern hemisphere of high latitude was $\sim 440 \mathrm{nT}$. In contrast to June solstice between $90^{\circ} \mathrm{N}$ and $180^{\circ} \mathrm{E}$, reduced $\mathrm{Sq}(\mathrm{H})$ magnitude of $\sim 160 \mathrm{nT}$ was as well observed.

Although, previous work of Campbell (1976) has shown highest magnitude of $\mathrm{Sq}(\mathrm{H})$ at high latitude compared to other latitudes. However, he could not distinguish $\mathrm{Sq}(\mathrm{H})$ magnitudes between the northern and southern hemisphere. He attributed this highest $\mathrm{Sq}(\mathrm{H})$ magnitude at high latitudes to their closeness to the polar cap that easily accesses any available release energies from magnetospheric sources. Our results have shown high magnitudes of $\mathrm{Sq}(\mathrm{H})$ at high latitude compare to other latitudes. The highest value of $\sim 440 \mathrm{nT}$ was observed at the southern hemisphere during D-season. The $\mathrm{Sq}(\mathrm{H})$ magnitudes were moderate at equatorial zone and sometimes enhanced and at the middle latitude, $\mathrm{Sq}(\mathrm{H})$ magnitudes are lower. Similar results have been reported by Yacob and Rao (1965); Maeda (1968); Suzuki (1973); Santarelli et al. (2007); Pham Thi Thu et al. (2011); Yamazaki et al. (2011). At middle and equatorial latitudes, they observed a higher magnitude of $\mathrm{Sq}(\mathrm{H})$ during the summer months, which is equivalent to June (J) season and a lowest magnitude during the winter months, which is equivalent to December (D) season. But, at the southern hemisphere of high latitude, summer period is experience when the northern hemisphere of the high latitude is in winter period. Hence, the highest magnitude of $\mathrm{Sq}(\mathrm{H})$ observed at the southern hemisphere of high latitude during D-season.

In conclusion, the study has shown the existence of seasonal variation of worldwide $\mathrm{Sq}(\mathrm{H})$ with the following characteristics:

1) Solstitial asymmetry: the December solstice $\mathrm{Sq}(\mathrm{H})$ magnitude $(\sim 440 \mathrm{nT})$ and located at the high latitudes south eastern part of the globe is greater than June solstice $\mathrm{Sq}(\mathrm{H})$ magnitude $(\sim 320 \mathrm{nT})$ located at the high latitudes north eastern part of the globe.

2) Equinoctial asymmetry: the autumn $\mathrm{Sq}(\mathrm{H})$ magnitude $(240 \mathrm{nT}-440 \mathrm{nT})$ at the high latitudes North western and $(220 \mathrm{nT}-320 \mathrm{nT})$ at the high latitude south eastern part of the globe is greater that the spring $\mathrm{Sq}(\mathrm{H})$ magnitude ( $220 \mathrm{nT}-300 \mathrm{nT}$ ) at the high latitudes north western part of the globe and $220 \mathrm{nT}$ at the high latitudes south western part of the globe.

\section{Acknowledgments}

The authors thank INTERMAGNET for the provision of data used in this research work at no cost.

\section{References}

Akasofu, S. I., \& Chapman S. (1972). Solar -Terrestrial Physics. Oxford: Oxford University Press.

Alldredge, L. R. (1977). Geomagnetic variations with periods from 13 to 30 years. J. Geomag. Geoelectr., 29, 123-135.

Bloxham, J. (1992). The steady part of the secular variation of the Earth's magnetic field. Journal of Geophysical Research, 97(B13). http://dx.doi.org/10.1029/92JB01469

Bolaji, O. S., Adimula, I. A., Adeniyi, J. O., \& Yumoto, K. (2013). Variability of Horizontal Magnetic Field Intensity Over Nigeria During Low Solar Activity. Earth Moon Planets, an International Journal of Solar System Science. http://dx.doi.org/10.1007/s11038-012-9412-0

Brown, G. M., \& Williams, W. R. (1969). Some properties of the day-to-day variability of $\mathrm{Sq}(\mathrm{H})$, Planet. Space Sci., 17, 455-470.

Campbell, W. H. (1977). Spectral Characteristics of Field Variations during Geomagnetically Quiet Conditions. J. Geomag. Geoelectr., 29, 29-50.

Campbell, W. H. (1981). Annual and semiannual variations of the geomagnetic field at equatorial locations. $J$. atmos. Terr. Phys., 43, 607-616. 
Campbell, W. H. (1987). Some effects of quiet geomagnetic field changes upon values used for main field modeling. Phys. Earth Planet Inter., 48, 193-199.

Campbell, W. H. (1997). Introduction to Geomagnetic fields. New York: Cambridge University Press.

Canton, J. (1759). An Attempt to Account for the Regular Diurnal Variation of the Horizontal Magnetic Needle; And Also for Its Irregular Variation at the Time of an Aurora Borealis Philosophical Transactions (1683-1775) (Vol. 51, pp. 398-445).

Chapman, S. (1951). Some phenomena of the upper atmosphere. Proc. Phys. Soc., London, B 64, 833-843.

Chapman, S., \& Bartels, J. (1940), Geomagnetism. Oxford: Oxford University Press.

Currie, R. G. (1966). The geomagnetic spectrum-40 days to 5.5 years. Geophys. Res, 71, 4579-4593.

Forbes, J. M. (1981). The equatorial Electrojet. Rev. Geoph. Space Phys., 19, 469-504.

Gauss, C. F. (1839). Allgemeine Theorie des Erdmagnetismus (p. 1).

Greener, J. G., \& Schlapp, D. M. (1979). A study of day-to -day variability of Sq over Europe. J. atmos. Terr. Phys., 41, 217-223.

Hibberd, F. H., \& Henderson, T. L. E. (1967). Sq current effects on the seasonal variations in the E-region of the ionosphere. J. atmos. Terr. Phys., 29, 477-488.

Maeda, H. (1968). Variation in geomagnetic field. Space Sci. Rev., 8, 555-590.

Malin, S. R. C., \& Gupta, J. C. (1977). The Sq current system during the International Geophysical Year. Geophys. J. R. astron. Soc., 49, 515-529.

Matsushita, S. (1969). Dynamo currents, Winds and Electric fields. Radio Sci., 4, 771.

Matsushita, S., \& Campbel, W. H. (1967). Physics of Geomagnetic Phenomena (Vol. 1). New York: Academic Press.

Matsushita, S., \& Maeda, H. (1965). On the geomagnetic solar quiet daily variation field during the IGY. $J$. Geophys. Res., 70, 2535-2558.

Matveyenkov, I. T. (1983). Possible effects of distant field sources on Sq variations. Geomagnetism and Aeronomy, 23, 276-277.

Maynard, H., Riehl, H., \& Berry, F. A. (1955). Exploration of the Jet Stream by Aircraft during the 1952-1953 Winter. Journal of Atmospheric Sciences, 12(1), 26-35.

Mcintosh, D. H. (1959). On the annual variation of magnetic disturbance. Phil. Trans. Roy. Soc. London, A., 251, 525-552.

Mitra, S. K. (1947). The Upper Atmosphere. The Royal Asiatic society of Bengal, Calcutta.

Okeke, F. N., Onwumechili, C. A., \& Rabiu, A. B. (1998). Day to day variability of geomagnetic hourly amplitudes at low latitude. Geophys. J. Int., 134, 484-500.

Olsen, N. (1996). Magnetospheric contributions to geomagnetic daily variations. Ann. Geophysicae, 14, 538-544.

Onwumechili C. A. (1960). Fluctuation in the geomagnetic field near the magnetic equator. J. atmos. Terr. Phy., 17, 286-294.

Onwumechili C. A. (1997). The Equatorial Electrojet. Netherlands: Gordon and Breach Science Publishers.

Onwumechili, C. A., \& Ezema, P. O. (1977). On course of the geomagnetic daily variation in low latitude. $J$. atmos. Terr. Phys., 39, 1079-1086.

Onwumechili, C. A., \& Ogbuehi, P. O. (1962). Fluctuations in the geomagnetic horizontal field. J. atmos. Terr. Phys., 24, 173-190.

Onwumechili, C. A., Oko, S. O., \& Ezema, P. O. (1996). Geomagnetically quiet day ionospheric currents over the Indian sector-I. Worldwide part of Sq currents. J. atmos. Terr. Phys., 58, 541-553.

Price, A. T. (1963). The non cyclic variation during quiet days. J. Geophys. Res., 6, 2445-2451.

Price, A. T., \& Wilkins, G. A. (1963). New methods for the analysis of geomagnetic fields and their application to the Sq field of 1932-3, Phil. Trans., A, 256, 31-98.

Rabiu, A. B., Yumoto, K., Falayi, E. O., Bello, O. R., MAGDAS/CPMN Group. (2011). Ionosphere over Africa: 
Results from Geomagnetic Field Measurements During International Heliophysical Year IHY. Sun and Geosphere, 6(2).

Rabiu, A. B. (1996). Night time geomagnetic variations at middle latitudes. Nigerian Journal of Physics, 8 , 35-37.

Rabiu, A. B. (2002). Seasonal Variability of Sq at Middle Latitudes. Nig. Journ. of Phys., 14(I), 66-71.

Rabiu, A. B., Nagarajan, Okeke, F. N., Ariyibi, E. A., Olayanju, G. M., Joshua, E. O., \& Chukwuma, V. U. (2007). A study of day to day variability in geomagnetic field variations at the Electrojet zone of Addisa baba,East Africa. Journal of Science and Technology (AJST), 8(2), 54-63.

Rastogi, R. G. (1993). Geomagnetic field variation at low latitudes and ionospheric electric fields. Journal of Atmospheric and Terrestrial Physics, 55, 1375-1381.

Rastogi, R. G. \& Iyer, K. N. (1976). Quiet Day Variation of Geomagnetic H-Field at Low Latitudes. J. Geomag. Geoelectr., 28, 461-479.

Rastogi, R. G., \& Patil, A. R. (1992). On certain aspects of' daily variation of geomagnetic field at low latitudes. J. Geomag, Geoelectr., 44, 495-503.

Rastogi, R. G., Rao, D. R. K., Alex, S., Pathan, B. N., \& Sastry, T. S. (1997). An intense SFE and SSC event in geomagnetic H, Y, and Z fields at the Indian chain of observatories. Ann. Geophysicae, 15, 1301-1308.

Regan, R. D., \& Rodriguez, P. (1981). An overview of the external magnetic field with regard to magnetic surveys. Geophysical Surveys, 4, 255-296.

Sabine, E. (1852). On Periodical Laws Discoverable in the Mean Effects of the Larger Magnetic Disturbances. Philosophical Transactions of the Royal Society of London, 142, 103-124.

Santarelli, L., Cafarella, L., Lepidi, S., Di Mauro, D., Meloni, A., \& Palangio, P. (2007). Fourteen years of geomagnetic daily variation at Mario Zucchelli Station (Antartica). Annals of Geophysics., 50, 2.

Schlapp, D. M. (1968). World-wide morphology of day-to-day variability of Sq. J. atmos. Terr. Phys., 30, 1761-1776.

Schuster, A. (1889). The diurnal variation of terrestrial magnetism. Phil. Trans. Roy. Soc. London, Ser. A., 180, 467-518.

Shea, M. A., \& Smart, D. F. (1998). Space weather: The effects on operations in space. Adv. Space Res., 22, 29-38.

Stening, R., Reztsova, T., Ivers, D., Turner, J., \& Winch, D. (2005). Morning quiet -time ionospheric current reversal at mid to high latitudes. Annals of Geophysics, 23, 385-391.

Stening, R. J. (1971). Longitude and seasonal variations of the Sq current system. Radio Sci., 6, 133-137.

Stewart, B. (1882). On the Connexion between the State of the Sun's Surface and the Horizontal Intensity of the Earth's Magnetism. Proceedings of the Royal Society of London, 34, 406-409.

Sugiura, M., \& Hagan, M. P. (1967a). Universal-time changes in the geomagnetic solar quiet daily variation Sq, Sci. Rep., Dep. Atmos. Sci., Univ. Wash.

Sugiura, M., \& Hagan, M. P. (1967b). A study of seasonal changes in the geomagnetic Sq variation by a motion picture representative $S q$, Sci. Rep., Dep. Atmos. Sci., Univ. Wash.

Suzuki, A. (1973). A new analysis of the geomagnetic Sq field. J. Geomag. Geoelectr., 25, 259-280.

Suzuki, A. (1978). Geomagnetic Sq field at successive universal times. Journal of Atmospheric and Terrestrial Physics, 40, 449-463.

Suzuki, A. (1979). UT and Day-to-Day Variations in Equivalent Current Systems for World Geomagnetic Variations. J. Geomag. Geoelectr., 31, 21-46.

Takeda, M. (1984). Day to day variation of equivalent Sq current system during March 11-26, 1976. J. Geomag. Geoelectr., 36, 215-228.

Takeda, M. (1999). Time variation of global geomagnetic Sq field in 1964 and 1980. Journal of Atmospheric and Terrestrial Physics, 61, 765-774.

Takeda, M., \& Iyemori, T. (2003). Relationship between electric field and currents in the ionosphere and the geomagnetic Sq field. J. of Geophys. Res., 108(A5), 1183. 
Tarpley, J. D. (1973). Seasonal movement of the Sq current foci and related effects in the equatorial electrojet. Journal of Atmospheric and Terrestrial Physics, 35, 1063-1071.

Van Sabben, D. (1964). North-South asymmetry of sq. Journal of Atmospheric and Terrestrial Physics, 26(12), 1187-1195.

Van Sabben, D. (1966). Meridional currents in the equatorial electrojet region. Journal of Atmospheric and Terrestrial Physics, 28(12), 965-979.

Vestine, E. H. (1947). In. S. Matsushita \& W. H. Campbell (Eds.). Main geomagnetic field in Physics of Geomagnetic Phenomena (Vol. I, pp. 181-234). New York: Academic Press.

Vestine, E. H. (1954). Winds in the upper atmosphere deduced from the dynamo theory of geomagnetic disturbance. J. Geophys. Res., 59, 93-128.

Yacob, A., \& Prabhavalkar, A. S. (1965). Solar control of the amplitude and phase of the yearly mean $\mathrm{Sq}(\mathrm{H})$ at Alibag for the period 1905 to 1960. Journal of Atmospheric and Terrestrial Physics, 27, 73-80.

Yacob, A. R., \& Rao, D. R. (1966). Solar cycle and annual variations of Sq(H) at Alibag. Journal of Atmospheric and Terrestrial Physics, 28, 351-388.

Yamazaki, Y., Yumoto, K., Uozumi, T., \& Cardinal, M. G. (2011). Intensity variations of the equivalent Sq current system along the $210^{\circ}$ magnetic meridian. J. of Geophys. Res., 116, A10308. http://dx.doi.org/10.1029/2011JA016632

\section{Copyrights}

Copyright for this article is retained by the author(s), with first publication rights granted to the journal.

This is an open-access article distributed under the terms and conditions of the Creative Commons Attribution license (http://creativecommons.org/licenses/by/3.0/). 